\title{
Water Balance and Climatic Classification of the Cauvery River Basin, India
}

\author{
M. Sambasiva Rao ${ }^{1}$, T. Somasekhara Reddy ${ }^{2}$, K. Somanna ${ }^{3}$ \\ ${ }^{1}$ Professor, Department of Geography, Sri Krishnadevaraya University, Anantapuram- 515 003, India \\ ${ }^{2,3}$ Post Doctoral Fellows, Department of Geography, Sri Krishnadevaraya University, Anantapuram- 515003 , India
}

\begin{abstract}
The Cauvery basin covering an area of about $81,155 \mathrm{~km}^{2}$ has been studied with view to explain the spatial distribution of water balance elements like potential evapotranspiration, actual evapotranspiration, water deficit, water surplus, moisture adequacy, Aridity Index and Moisture Index. From about 37 stations the mean monthly rainfall and mean monthly temperature is collected over a period of fifty years. Applying Thornthwaite and Mather (1955) book keeping procedure the monthly, seasonal and annual water balance elements of the Cauvery basin are worked out and mapped. The annual recharge of the Cauvery basin has been worked out using rainfall recharge method. From the analysis it is found that the Western Ghats, Nilagiris and Kodaikanal hills of the Cauvery basin experiences water surplus. The central and eastern plains of the basin experience water deficit. From the analysis of water balance it is found that out of total surface water resources of 105, 109, 725, $000 \mathrm{~m} 3$ about $10 \%$ is stored in surface tanks, ponds and reservoirs, $15.06 \%$ is recharged to ground water, $30 \%$ is lost in the form of surface run-off and $44.94 \%$ of the water is lost in the form of evaporation and evapotranspiration. The Western Ghats, Nilagiris and Kodaikanal hills experience to per humid and humid type of climate. The Mysore plateau region experiences wet sub humid and dry sub humid types of climate. The central and eastern plains of the Cauvery basin experience dry sub humid type of climate.
\end{abstract}

Keywords: precipitation, potential evapotranspiration, actual evapotranspiration, water deficit, water surplus, Aridity Index

\section{Introduction}

Water balance is the study of water input in the form of precipitation and water loss in the form of evaporation and evapotranspiration Thornthwaite Mather (1955) have developed a book keeping procedure to work out water balance of elements namely potential evapotranspiration, actual evapotranspiration, water deficit, water surplus, moisture adequacy and Aridity Index. Hemamalini (1979) has studied the eco-climatology of Andhra Pradesh. Subrahmanyam (1982) has published a monograph on water balance and its applications. Aridity Index studies on water balance elements of Tamil Nadu state are carried out, by Ram mohan (1978 and 1980), Sambasiva Rao (1984, 1996 and 2002) Padmini (1989) and Sambasiva Rao and Kalavathy (1983). Rajeswari (1990) described the water balance elements and cropping pattern of Madurai, Ramanathapuram and Puddukkothai districts of Tamil Nadu. Madhuramma (1991 and 1992) has studied the water balance elements and cropping pattern of Nellore district, Andhra Pradesh. Suresh babu (1993) has studied the water balance and drought climatology of Anantapur district, Andhra Pradesh. Samuel Raju (1996) has studied the drought climatology, water balance and development of land and water resources of Kurnool district, Andhra Pradesh. Raveendra (2013) has studied the water balance, drought analysis and watershed development of the Anantapur district of Andhra Pradesh, Somanna (2013) has studied the Water balance and cropping pattern of the Rayalaseema region. The water balance studies of river basins are carried out by Subramanyam etal. (1970), Subrahmanyam and Kamaraju (1983), Subrahmanyam and Venkatesh (1984) and Sambasiva Rao (2002, 2005 \& 2012).

\section{Study Area}

The Cauvery river basin covers an area of about $81,155 \mathrm{~km}^{2}$. It lies in Karnataka, Kerala, Tamil Nadu and Pondicherry states of southern India. The basin is located in between $10^{\circ}$ $05^{\prime}$ North and $13^{\circ}-30^{\prime}$ North latitudes and $75^{\circ}-30^{\prime}$ East and $79^{0}-45^{\prime}$ East longitudes. About $54.05 \%$ of the Cauvery basin covering $43,867 \mathrm{~km}^{2}$ falls in the Tamil Nadu state, about $42.23 \%$ of the basin covering $34,273 \mathrm{~km}^{2}$ lies in the Karnataka state, about $3.53 \%$ covering an area of about 2 , $866 \mathrm{~km}^{2}$ falls in Kerala state and about $0.18 \%$ covering an area of about $149 \mathrm{~km}^{2}$ lies in the Pondicherry state. The mean annual rainfall of the basin $1295 \mathrm{~mm}$. Geologically the basin is formed of Precambrian rocks consisting of Dharwar peninsular granitic gneisses, charnockites, and clospet granites. The basin is divided into three major physiographic regions namely the Western Ghat area, the plateau of Mysore and all the undulating, rolling and deltaic plains. The major tributaries of the Cauvery river are kabani, kadanur, kummahole, Harangi, Hemavathi, Shimsha, Arkavathy, Lakshmanatirtha, Kabbari, Suvarnavathi, Bhavani, Noyyal and Amaravathi.

Climatologically the western part of the basin enjoys humid climate, and the northern, central and eastern part of the basin enjoys dry-humid climate.

\section{Objectives}

The main objectives of the present study are;

1) To study the mean of monthly, seasonal and annual rainfall and evaluate the surface water resources of the Cauvery basin,

2) To describe the seasonal and annual water balance elements of the Cauvery basin, 


\section{International Journal of Science and Research (IJSR) \\ ISSN (Online): 2319-7064}

Index Copernicus Value (2013): 6.14 | Impact Factor (2015): 6.391

3) To bring out the annual recharge and the water balance of the Cauvery basin and

4) To describe the climatic classification of the Cauvery basin.

\section{Methodology}

The data pertaining to monthly rainfall over a period of hundred years has been collected from 39 stations from Indian Meteorological department (IMD), Government of India, Pune and local Meteorological stations. Similarly the data pertaining to monthly temperature for a period of fifty years has been collected from IMD (Indian Meteorological department) and local Meteorological stations. The monthly data of rainfall and temperature is used to work out water balance elements applying Thornthwaite and Mather (1955) book keeping procedure. The monthly potential evapotranspiration (PE), actual evapotranspiration (AE), water deficit (WD) and water surplus (WS) are worked out. Basing on the monthly values of potential evapotranspiration and actual evapotranspiration the monthly moisture adequacy is worked out. Similarly basing on the values potential evapotranspiration and water deficit, the Aridity Index is worked out. The Moisture Index of each station on monthly, seasonal and annual is worked out. Basing on the values of Moisture Index the climatic classification of the Cauvery basin is brought out. The recharge is worked out adopting Radhakrishna etal. (1974) method, U.S. Geological (1985) method, Seghal (1970) method and Krishna Rao (1970) method. The recharge is worked out for 38 stations using four different methods and average of the four methods is taken as the annual recharge of the Cauvery basin.

\section{Results}

Mean monthly, seasonal and annual rainfall of the Cauvery basin:

The mean monthly rainfall of the Cauvery varies from a minimum of $14 \mathrm{~mm}$ in the month of February to a maximum of $202 \mathrm{~mm}$ in the month of July. The mean rainfall is less than $50 \mathrm{~mm}$ in January, February and March months. It varies from $50 \mathrm{~mm}$ to $100 \mathrm{~mm}$ in April, May and December months. The mean monthly rainfall of the basin ranges from $150 \mathrm{~mm}$ to $200 \mathrm{~mm}$ in June, August, September, October and November months. The mean monthly rainfall exceeds $200 \mathrm{~mm}$ in July month only. The mean seasonal analysis of the rainfall of the basin depicts that the basin receives minimum rainfall of $33 \mathrm{~mm}$ in winter period and the maximum rainfall of $676 \mathrm{~mm}$ is noticed in southwest monsoon period. During summer period the mean rainfall is $174 \mathrm{~mm}$ and in northeast monsoon period it is $412 \mathrm{~mm}$. The mean annual rainfall of the Cauvery basin is $1295 \mathrm{~mm}$ (Table. 1 and Fig. 1). The spatial distribution of the average annual rainfall is more than $2000 \mathrm{~mm}$ in Western Ghats and Nilagiris parts of the basin. It ranges from $1000 \mathrm{~mm}$ to $2000 \mathrm{~mm}$ in the Mysore plateau region, $750 \mathrm{~mm}$ to $1000 \mathrm{~mm}$ in the eastern plateau and central parts of the basin and more than $1000 \mathrm{~mm}$ in the eastern parts of the basin. The total surface water resources of the Cauvery basin is worked out as $105,095,725,000 \mathrm{~m}^{3}$ (Geographical area of the basin $\mathrm{X}$ Mean annual rainfall of the basin)

\section{Potential evapotranspiration}

The potential evapotranspiration (PE) is actual water need or water loss in the form of evapotranspiration. The average monthly PE values of the basin vary from $96 \mathrm{~mm}$ in December month to a maximum of $155 \mathrm{~mm}$ in May month. The seasonal potential evapotranspiration values range from $219 \mathrm{~mm}$ in winter period to a maximum of $570 \mathrm{~mm}$ in southwest monsoon period. The average potential evapotranspiration value in summer period is $439 \mathrm{~mm}$ and in northeast monsoon period it is $318 \mathrm{~mm}$. The average annual potential evapotranspiration value of the basin is $1546 \mathrm{~mm}$. The spatial distribution shows that the annual potential evapotranspiration value is less than $1300 \mathrm{~mm}$ in western parts of the basin in Western Ghats and the average annual potential evapotranspiration values range from $1300 \mathrm{~mm}$ to $1500 \mathrm{~mm}$ in Nilagiris and Mysore plateau region. The average annual potential evapotranspiration values vary from $1500 \mathrm{~mm}$ to $1700 \mathrm{~mm}$ in central parts of the Cauvery basin and it is more than $1700 \mathrm{~mm}$ in the eastern parts of the Cauvery basin. (Table. 2 and Fig. 2)

\section{Actual evapotranspiration (AE)}

The actual evapotranspiration is the actual water available for evapotranspiration. The average monthly actual evapotranspiration varies from a minimum of $69 \mathrm{~mm}$ in the March month to a maximum of $119 \mathrm{~mm}$ in the October month. The seasonal average of actual evapotranspiration values range from $166 \mathrm{~mm}$ in winter period to a maximum of $366 \mathrm{~mm}$ in southwest monsoon period. In the summer period the average actual evapotranspiration value is $220 \mathrm{~mm}$ and in northeast monsoon period it is $312 \mathrm{~mm}$. The average annual actual evapotranspiration is $1064 \mathrm{~mm}$. The spatial distribution shows that the actual evapotranspiration values are more than $1200 \mathrm{~mm}$ in the western parts of Nilagiris and Kodaikanal hills of the Cauvery basin, $1000 \mathrm{~mm}$ to $1200 \mathrm{~mm}$ in the Mysore plateau region and in the eastern parts of the basin. It is less than $1000 \mathrm{~mm}$ in central parts of the basin. (Table. 3 and Fig. 3)

\section{Water Deficit (WD)}

The water deficit (WD) is the difference between potential evapotranspiration and actual evapotranspiration. The average monthly water deficit values vary from $0 \mathrm{~mm}$ in October to a maximum of $79 \mathrm{~mm}$ in June months. The average monthly water deficit values are less than $50 \mathrm{~mm}$ in January, February, January, September, October, November, and December months. The monthly water deficit values range from $50 \mathrm{~mm}$ to $75 \mathrm{~mm}$ in March April, May, July, and August months. The average water deficit value is more than $75 \mathrm{~mm}$ in June month. The average seasonal water deficit values range from a minimum of $11 \mathrm{~mm}$ in winter period to a maximum of $250 \mathrm{~mm}$ in southwest monsoon period. The average water deficit value is $34 \mathrm{~mm}$ in winter period and $208 \mathrm{~mm}$ in summer period. The spatial distribution shows that there is no water deficit in the Western Ghats, Nilagiris and Kodaikanal hills of the Cauvery basin. The average water deficit is $500 \mathrm{~mm}$ to $800 \mathrm{~mm}$ in the central and eastern parts of the basin. (Table.4 and Fig. 4)

\section{Water Surplus}

The positive difference between precipitation and potential evapotranspiration is the water surplus. The average monthly water surplus is found in October and November months and 


\section{International Journal of Science and Research (IJSR) \\ ISSN (Online): 2319-7064 \\ Index Copernicus Value (2013): 6.14 | Impact Factor (2015): 6.391}

it varies from $51.90 \mathrm{~mm}$ to $53.3 \mathrm{~mm}$. There is no water surplus in January, February, March, May, June, July, August, September and December months. The water surplus is found in Western Ghats Nilagiris and Kodaikanal hills of Cauvery basin. (Table.5 and Fig.5)

\section{Moisture adequacy (Ima)}

The moisture adequacy (Ima) is the ratio in the percentage between actual evapotranspiration and potential evapotranspiration. It depicts the amount of moisture available for crop growth. The average Ima values vary from $45 \%$ in June month to a maximum of $100 \%$ in October and November months. The average Ima value is less than $50 \%$ in April, June and July months. The Ima values range from $50 \%$ to $75 \%$ in February, March, May, August and September months. The Ima values vary from $75 \%$ to $100 \%$ in January, October, November and December months. The seasonal Ima values range from $52 \%$ in summer period to a maximum of $96 \%$ in northeast monsoon period. The average annual moisture adequacy value is $67 \%$. The spatial distribution shows that the Ima value is $100 \%$ in Western Ghats, Nilagiris and Kodaikanal hills. It varies from $60 \%$ to $90 \%$ in Mysore plateau region and it is less than $60 \%$ in central and northeastern parts of the basin. In the southeastern parts the Ima value is more than $60 \%$.

\section{Aridity Index (Ia)}

The Aridity Index (Ia) is the ratio in the percentage between water deficit and potential evopotranspiration. The average Ia value varies from $0 \%$ in October and November months to a maximum of $55 \%$ in June month. The average Ia value is less than $50 \%$ in January, February, March, May, August, September, October, November and December months. The average Ia value is more than $50 \%$ in April, June and July months. The seasonal analysis of Ia values indicate that they vary from $4 \%$ in northeast monsoon to a maximum of $48 \%$ in summer period. The value of Ia is $17 \%$ in winter period and $45 \%$ in northeast monsoon period. The average annual Ia is $33 \%$. The spatial distribution shows that the Ia value is 0 percent in Western Ghats Nilagiris and Kodaikanal hills of the basin. It is less than $40 \%$ in the Mysore plateau region and more than $40 \%$ in the central and eastern parts of the basin.

\section{Moisture Index}

The Moisture Index is the index of moisture effectivity given by the equation.

$$
\operatorname{Im}=\mathrm{Ih}-0.6 \mathrm{Ia}
$$

Where $\mathrm{Im}$ is Moisture Index, $\mathrm{Ih}=$ Humidity Index (which is ratio in percentage of water surplus and potential evapotranspiration and Ia is the Aridity Index). For computation of Moisture Index the values of water surplus, water deficit and potential evapotranspiration are required. The annual Moisture Index values vary from $-33 \%$ in Namakkal to $+84.06 \%$ in Mereca. The annual moisture Index value in the western part of the hilly terrain varies from $+23.97 \%$ in Kodaikanal station to a maximum of $+84.06 \%$ in the Heggada, Devakote station. In the Mysore plateau region the annual values of Moisture Index ranges from $-24.4 \%$ in Mandya station to $-5.4 \%$ in Gudalur station. In the central part of the Cauvery basin the annual values of Moisture Index vary from $-33.0 \%$ in Namakkal station to $22.8 \%$ in salem station.
The seasonal Moisture Index values show that during winter period the Im values range from $-24.0 \%$ in Thiruchi station to $-1.2 \%$ in Mereca station. In southwest monsoon the values of Im in the hilly terrain range from $+17.97 \%$ in Madikera to $+276.52 \%$ in Mereca. In the Mysore plateau the values of Im vary from $-30.0 \%$ in Mandya to $-9.6 \%$ in Bangalore station. In the central parts of the Cauvery basin they range from $45.0 \%$ in Bavani sagar station to $-27.6 \%$ in Salem station. During northeast monsoon the values of Im in hilly terrain range from $-1.2 \%$ in Mysore to $+92.27 \%$ in Udagamandalam. In Mysore plateau region the Im values vary from $-22.2 \%$ in Bangalore to $-5.4 \%$ in Mandya. In the central part of the Cauvery basin the Im values range from $2.4 \%$ in Karur, Mettur and Salem stations to $-10.53 \%$ in Dindigul station. In the eastern parts of the Cauvery basin in northeast monsoon the Im values vary from $8.69 \%$ in Thiruchi station to $+181.09 \%$ in Vedaranyam station.

\section{Climatic Classification}

The Climatic classification of the Cauvery basin is brought out using the values of Moisture Index on seasonal and annual basis. During winter season the entire basin experiences dry sub-humid climate in all the stations of the basin. In summer season the central part of the basin experiences semi-arid climate and in other parts of the basin dry sub-humid type of climate is noticed. In southwest monsoon period the central and eastern parts of the basin experiences semi-arid type of climate and in Mysore plateau region dry sub-humid type of climate is found. The western hilly terrain possessed wet sub-humid, humid and per-humid climates. During northeast monsoon period the western hilly terrain experiences wet sub humid type of climate. The Mysore plateau region possessed dry sub-humid climate. In the central part of the Cauvery basin dry sub humid and wet sub-humid types of climate is found and in the eastern parts of wet sub humid, humid and per humid types of climate is noticed. The annual Moisture Index values show humid type of climate in the western hilly terrain, and dry sub-humid type of climate in Mysore plateau, central and eastern parts of the Cauvery basin.

\section{Annual recharge of surface water resources of the Cauvery basin:}

The annual recharge of the Cauvery basin is worked out for 38 stations in the basin using Radhakrishna etal. (1974) method U.S. Geological method, (1985), Segal method (1970) and Krishna Rao method (1970). The average of the four methods of 38 stations is taken as annual recharge of the Cauvery basin. According to Radhakrishna etal method (1974) the annual recharge is worked out as $10 \%$ of the annual rainfall. The annual recharge varies from $65.40 \mathrm{~mm}$ in Madya station to a maximum of $222.90 \mathrm{~mm}$ in Meraca station. The average annual recharge according to Radhakrishna etal. (1974) is 108.08mm (Table.2). According the U.S. Geographical method (1985) the annual recharge is $15 \%$ of the annual rainfall. The annual rainfall recharge according to this method varies from $98.10 \mathrm{~mm}$ in Madya station to a maximum of $334.35 \mathrm{~mm}$ in Mereca station. The average annual recharge is $162.12 \mathrm{~mm}$. According to Segal (1970) method the ground water recharge is $2.5(\mathrm{P}-16)^{0.5}$ where $\mathrm{P}$ is Precipitation in inches. According to the method the annual recharge ranges from $125.38 \mathrm{~mm}$ in Madya station to a maximum of $340.19 \mathrm{~mm}$ in 


\section{International Journal of Science and Research (IJSR) \\ ISSN (Online): 2319-7064 \\ Index Copernicus Value (2013): 6.14 | Impact Factor (2015): 6.391}

Mereca station. The average annual recharge is $206.94 \mathrm{~mm}$. According to Krishna Rao method (1970) the annual ground water recharge is $\mathrm{G}=\mathrm{K}(\mathrm{P}-\mathrm{X})$, where $\mathrm{G}=0.2(\mathrm{P}-400 \mathrm{~mm})$ when the annual rainfall ranges from $400 \mathrm{~mm}$ to $600 \mathrm{~mm}, \mathrm{G}=0.3(\mathrm{P}-$ $500 \mathrm{~mm}$ ) when the annual rainfall varies from $1000 \mathrm{~mm}$ to $2000 \mathrm{~mm}$. According to this method the annual recharge varies from $50.80 \mathrm{~mm}$ in Madya station to a maximum of $518.70 \mathrm{~mm}$ in Mereca station. The average annual recharge according to this method is $174.24 \mathrm{~mm}$.

The average annual recharge of the four methods worked out for 37 stations of the Cauvery basin varies from a minimum of $84.92 \mathrm{~mm}$ in Madya station to a maximum of $354.03 \mathrm{~mm}$ in Mereca station. The average annual recharge of the four methods of the 37 stations of the Cauvery basin is $162.84 \mathrm{~mm}$ which amounts to $15.06 \%$ of the average annual rainfall of $1080.82 \mathrm{~mm}$ of the Cauvery basin.

\section{Water Balance of the Cauvery Basin:}

1) The total annual surface water resources of the Cauvery basin : 105, 095, 725, $000 \mathrm{~m}^{3}$

2) The total annual surface water resources stored in the ponds, tanks, lakes, and reservoirs: 10, 509, 572, $500 \mathrm{~m}^{3}(10 \%)$

3) Total annual surface water resources recharged to groundwater : $15,827,416,185 \mathrm{~m}^{3}(15.06 \%)$

4) Total annual surface water resources lost in the form of run-off : $31,528,717,500 \mathrm{~m}^{3}(30 \%)$

5) Total annual surface water resources lost in the form of evaporation and potential evapotranspiration: 47, 230, $018,815 \mathrm{~m}^{3}(44.94 \%)$

From the analysis of water balance of the Cauvery basin it is found that out of total surface water resources of 105, 095, $725,000 \mathrm{~m}^{3}$ available, about $10 \%$ is stored in the ponds, tanks, lakes and reservoirs, $15.06 \%$ of the water resources is recharged annually to ground water, $30 \%$ of the total surface water resources is lost in the form of run-off and $44.94 \%$ of them is lost in the form of evaporation and evapotranspiration. From the analysis it is found that $74.94 \%$ of the total surface water resources is lost in the form of surface run-off and evaporation and potential evapotranspiration. The water resources lost in the form of surface run-off have to be carefully stored in the ponds, lakes, tanks and reservoirs through watershed development activities by constructing check dams, percolation ponds and water harvesting structures.

\section{Conclusions}

From the analysis of mean monthly rainfall it is found that during January, February and March months the mean monthly rainfall is less $50 \mathrm{~mm}$. It varies from $50 \mathrm{~mm}$ to $100 \mathrm{~mm}$ in April, May, June and December and it exceeds $100 \mathrm{~mm}$ in July, August, October and November months. The mean rainfall is more than $450 \mathrm{~mm}$ in southwest monsoon. The analysis of mean monthly potential evapotranspiration (PE) revealed that the mean $\mathrm{PE}$ is less than $100 \mathrm{~mm}$ in December month. It varies from $100 \mathrm{~mm}$ to $150 \mathrm{~mm}$ in February, March, April, May, July, August, September, October and November months. The mean monthly PE is more than $150 \mathrm{~mm}$ in May month. The mean $\mathrm{PE}$ is more than $500 \mathrm{~mm}$ in southwest monsoon period. The mean monthly actual evapotranspiration (AE) is less than $100 \mathrm{~mm}$ in January, February, March, April, May, June, July, August, September and December months. It is more than $100 \mathrm{~mm}$ in October and November months. The mean actual evapotranspiration is more than $300 \mathrm{~mm}$ in southwest and northeast monsoon periods. The mean water deficit (WD) is less than $50 \mathrm{~mm}$ in January, February, September and December months. The mean WD is more $50 \mathrm{~mm}$ in March, April, May, June, July and August months. The mean water surplus is found in October and November months. The water deficit exceeds $200 \mathrm{~mm}$ in summer and southwest monsoons. The mean moisture adequacy in less than $50 \%$ in April, June and July months. It is $100 \%$ in October and November months. In January, February, March, May, August, September and December months the Ima varies from $50 \%$ to $100 \%$. The mean Ima exceeds $80 \%$ in winter and northeast monsoon periods. The mean Aridity Index is less than 20\% in January, October, November and December months. It varies from $20 \%$ to $50 \%$ in February, March, May, August and September months. It exceeds 50\% in April, June and July months. The mean Ia is more than $40 \%$ in summer and southwest monsoon period. Climatologically the Cauvery basin as a whole experiences dry sub humid climate in January, February, March, April, May, June, July, August, September and December months. In November and December months humid type of climate is found. The average annual recharge is $162.84 \mathrm{~mm}$ which accounts to $15.06 \%$ of the mean annual rainfall.

\section{References}

[1] Hemamalini, B (1979), Studies in Eco-climatology of Andhra Pradesh Unpublished Ph.D thesis submitted to Andhra University, Waltair pp.167.

[2] Krishna Rao P.R (1970) Groundwater potential in hard rock area of India. Publication of Government of Karnataka, Bangalore.

[3] Maduramma, Ch. (1991) Water balance and cropping pattern of Nellore district. Unpublished M.phil thesis submitted to Sri Krishnadevaraya University Anantapur.

[4] Maruramma, Ch. (1992) Water balance, water availability and crop management of the Nellore district, Andhra Pradesh, India. Unpublished Ph.D thesis submitted to Sri Krishnadevaraya University.

[5] Padmini, R (1989) Water balance, land use efficiency and agriculture development of Athoor block, Anna district, Tamil Naidu. Unpublished M.Phil thesis submitted to Madurai Kamaraj University Madurai.

[6] Radha Krishna, B.P. Dushan Duba and Palimquist, W.N. (1974) Groundwater studies. No.50 Publication of Government of Karnataka, Bangalore.

[7] Rajeswari, M (1990) An analysis of water balance elements, water resources, cropping pattern and irrigation of Madurai, Ranganathapuram and Puddukkottai districts, Tamil Nadu. Unpublished Ph.D thesis submitted to Madurai Kamaraj University Madurai. pp. 272.

[8] Rammohan. H.S. (1978) A study of water balance and drought climatology of Tamil Nadu. Unpublished Ph.D thesis submitted to Andhra University Waltair.

[9] Rammohan. H.S. (1980) A climatological assessment of the water resources of the Tamil Nadu state. Proceed of the symposium on the water resources of the southern 


\section{International Journal of Science and Research (IJSR) \\ ISSN (Online): 2319-7064}

Index Copernicus Value (2013): 6.14 | Impact Factor (2015): 6.391

states. Department of Geography, Madurai Kamaraj University, Madurai.

[10] Raveendra M (2013) water balance, drought climatology and watershed development of the Anantapur district, Andhra Pradesh, India. Unpublished Ph.D thesis submitted to Sri Krishnadevaraya University, Ananthapur pp.247.

[11] Sambasiva Rao, $M$ and Kalavathy (1983) Water balance and cropping pattern in Madurai district, Tamil Nadu. The Indian Geographical Journal No. 58, No.2 pp.172 to 182 .

[12] Sambasiva Rao, M (1984) Planning and development of land and water resources of Madurai district, Tamil $\mathrm{Nadu}$, India. Unpublished project report submitted to Madurai Kamaraj University, Madurai. pp.202.

[13] Sambasiva Rao, M (1996) water balance and development of land, water and Agriculture resources of Tamil Nadu state, India. Unpublished project report submitted to University Grants Commission, New Delhi. Pp.

[14] Sambasiva Rao, M (1997) Eco-climatology, water balance, ecological degradation, and eco development of the Nallamalai and Erramalai hills of Eastern Ghats, Andhra Pradesh, India. Unpublished project report submitted to Ministry of Environment and Forest Resources, Government of India, New Delhi. pp.146.

[15] Sambasiva Rao, M (2002) Applied geomorphology, morphological evolution, water balance, cropping pattern and development of the land and water resources of the Pennar river basin. Unpublished project report submitted to University Grants Commission, New Delhi. pp.111.

[16] Sambasiva Rao, M (2005) An integrated study of geo ecology, geo hydrology and watershed development of the Papagni river basin of Andhra Pradesh, India. Using
Remote sensing and GIS technique. Unpublished project report submitted to University Grants Commission, New Delhi. pp.270.

[17] Sambasiva Rao, M (2012) Geomorphic evolution, water balance and development and water resources of the Kunderu basin, using GIS and Remote sensing techniques, Andhra Pradesh, India. pp.87.

[18] Samuel Raju, B. (1196) Drought climatology, Water balance and development of land and water resources of the Kurnool district, Andhra Pradesh. Unpublished Ph.D thesis submitted to Sri Krishnadevaraya University, Ananthapur. pp.

[19] Seghal S.R. (1970) Ground water recharge. International Hydrological Decade News Letter, India. No.5, pp.6.

[20]Somanna, K (2013) Water balance and Cropping pattern of the Rayalaseema region, Andhra Pradesh, India. Unpublished Ph.D thesis submitted to Sri Krishnadevaraya University, Anantapur pp.381.

[21] Subramanyam V.P.(1982) Water balance and its application with special reference to India. A monograph published by Andhra University Press, Waltai. pp.102.

[22] Suresh Babu. R (1993) Water balance, drought climatology. Cropping pattern and land and water resources development of Anantapur district, Andhra Pradesh, India. Unpublished Ph.D Thesis submitted to Sri Krishnadevaraya University, Anantapur. pp.455.

[23] Thronthwaite, C.W. and Mather, J.R. (1955) The Water Balance in Climatology, Laboratory of Climatology. Centerton (NJ), Vol.8, No.1, Pp.104.

[24] U.S. Geological method (1985) Groundwater Manual. A water resources technical publication U.S. department of the Interior, Scientific Publisher, Jodhpur. Pp.480.

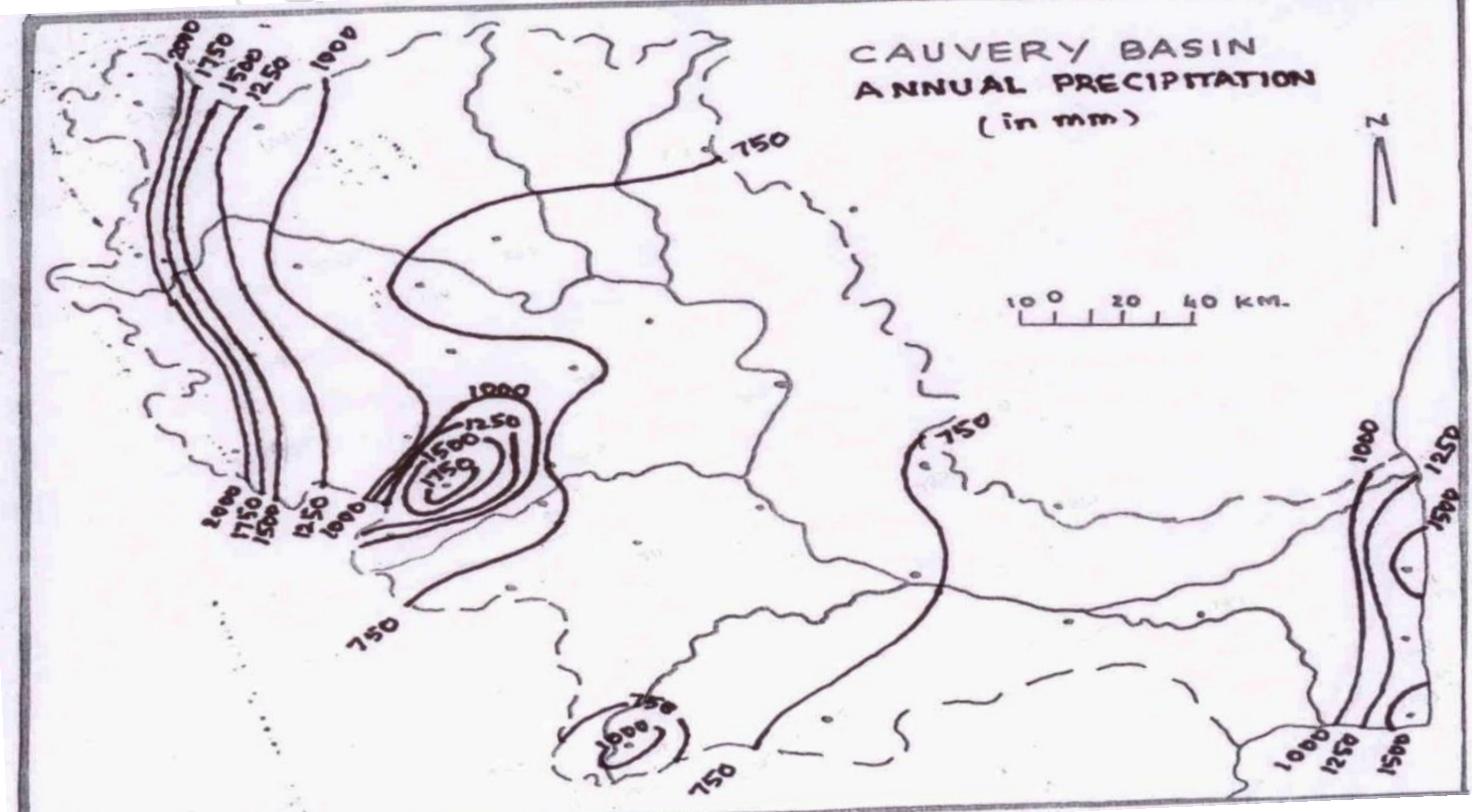

Figure 1 


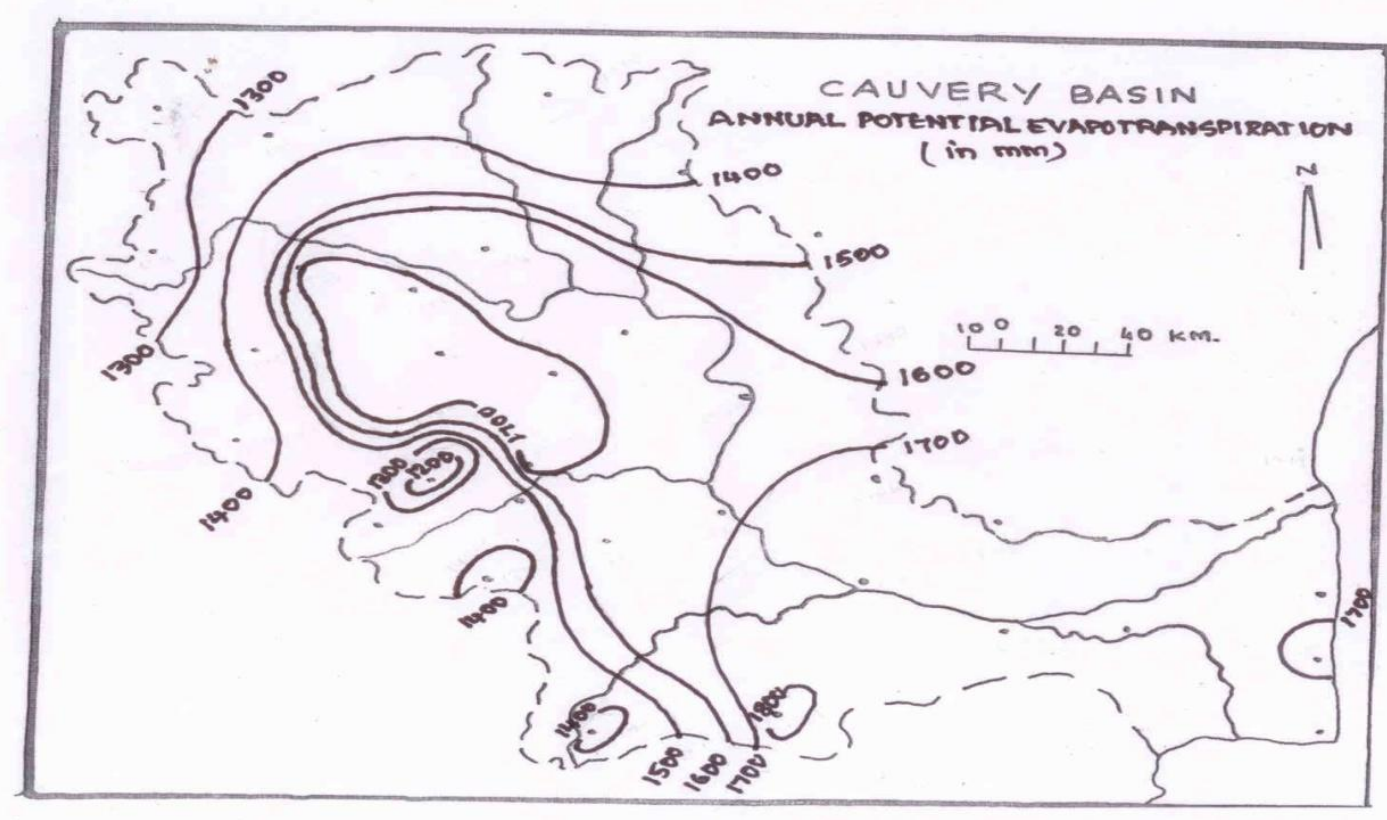

Figure 2

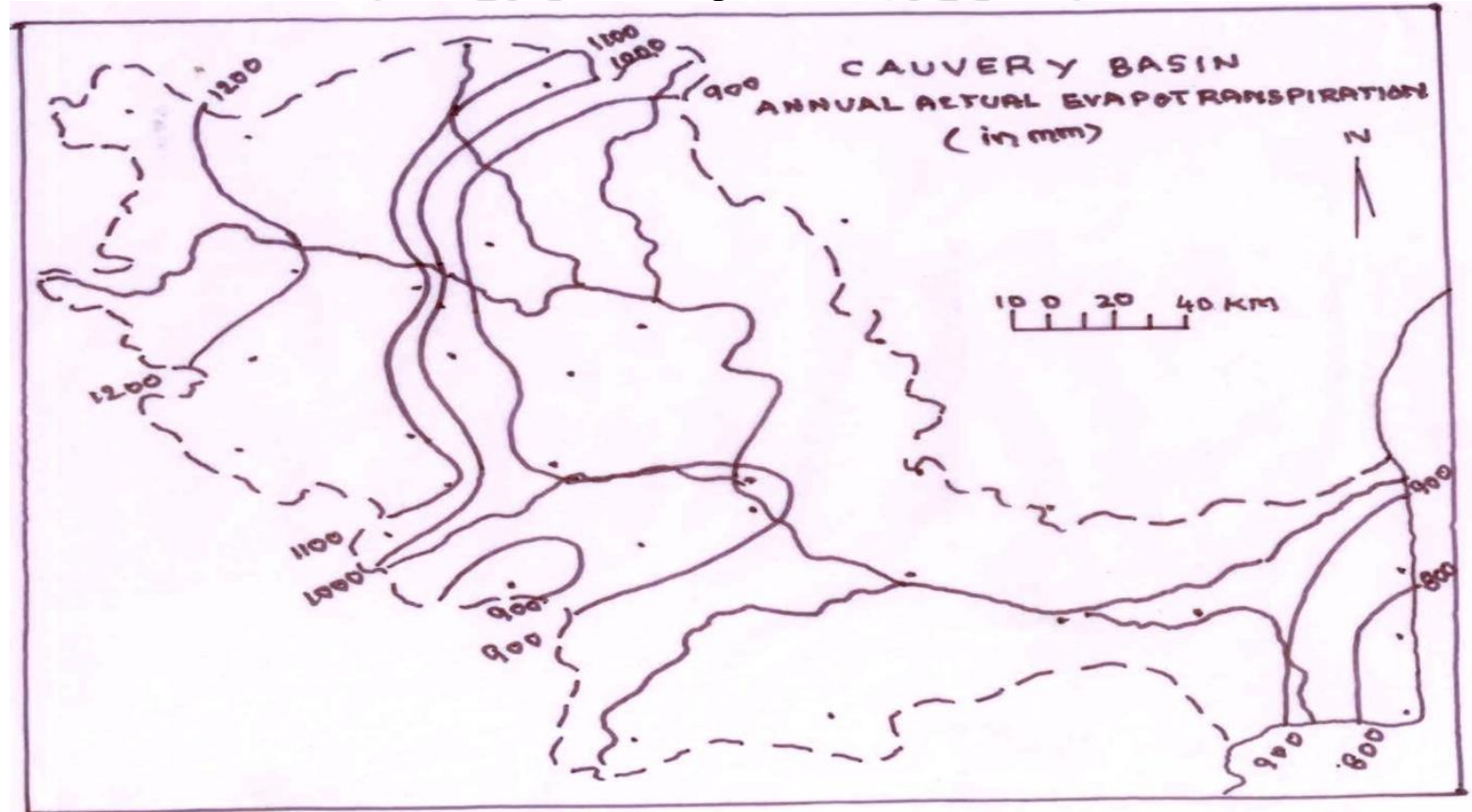

Figure 3 


\section{International Journal of Science and Research (IJSR) \\ ISSN (Online): 2319-7064}

Index Copernicus Value (2013): 6.14 | Impact Factor (2015): 6.391

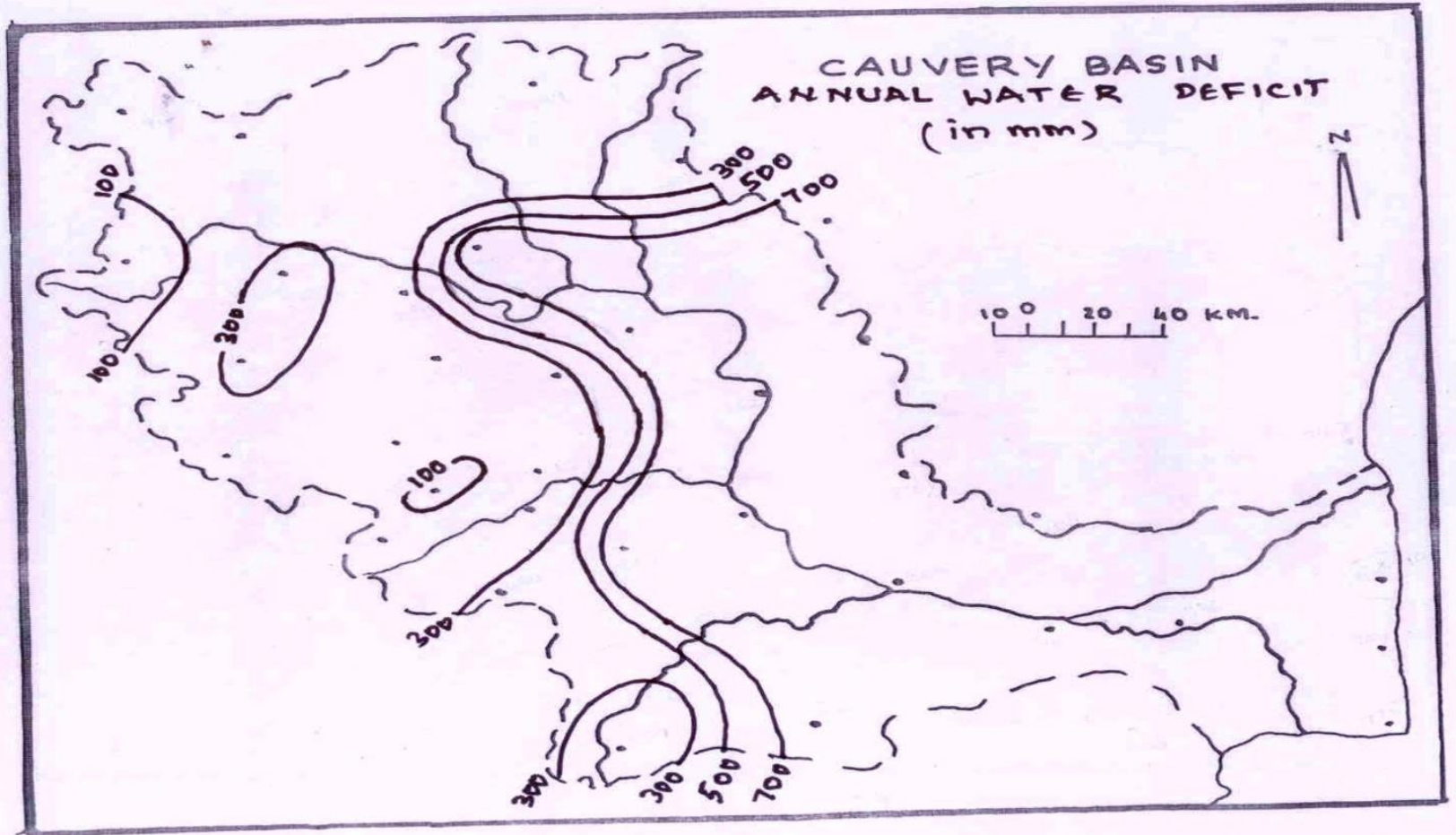

Figure 4

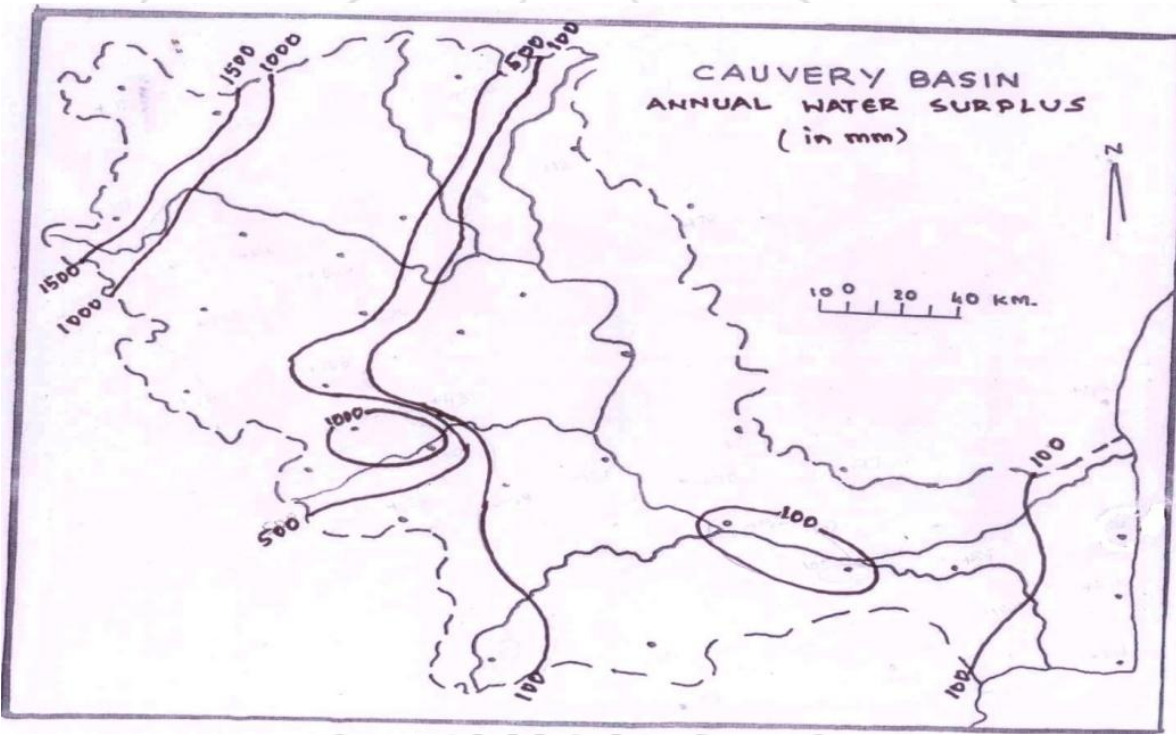

Figure 5

Table 1: Average Monthly, Seasonal and Annual Precipitation Values of the Stations of the Cauvery Basin In Mm

\begin{tabular}{|c|c|c|c|c|c|c|c|c|c|c|c|c|c|c|c|c|c|c|}
\hline$\underset{\text { is }}{\stackrel{0}{2}}$ & 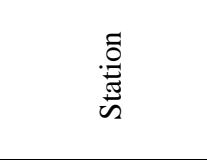 & $\begin{array}{l}\stackrel{\vec{\Xi}}{\Xi} \\
\stackrel{\Xi}{\Xi}\end{array}$ & 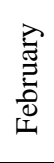 & 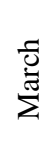 & $\overline{\bar{z}}$ & $\stackrel{\vec{\Xi}}{\Sigma}$ & $\stackrel{\Xi}{\Xi}$ & $\vec{\Xi}$ & 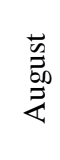 & 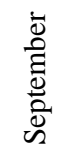 & $\begin{array}{l}\bar{\Delta} \\
\stackrel{0}{0} \\
0\end{array}$ & 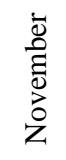 & 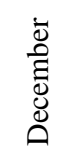 & 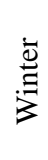 & 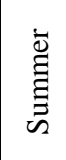 & 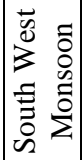 & 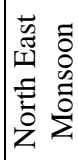 & $\begin{array}{l}\text { 胥 } \\
\text { 息 }\end{array}$ \\
\hline 1 & Avanashi & 6 & 4 & 17 & 57 & 102 & 36 & 36 & 59 & 97 & 179 & 101 & 47 & 10 & 176 & 228 & 327 & 741 \\
\hline 2 & Bangalore & 2 & 2 & 15 & 43 & 103 & 84 & 108 & 168 & 116 & 94 & 88 & 15 & 4 & 161 & 476 & 197 & 838 \\
\hline 3 & Belur & 3 & 8 & 57 & 57 & 90 & 402 & 650 & 293 & 290 & 166 & 120 & 18 & 11 & 204 & 1635 & 304 & 2754 \\
\hline 4 & Bhavani Sagar & 8 & 14 & 18 & 51 & 103 & 68 & 78 & 37 & 73 & 177 & 105 & 65 & 22 & 172 & 256 & 347 & 797 \\
\hline 5 & Charmajanagar & 8 & 10 & 25 & 85 & 82 & 246 & 365 & 203 & 205 & 170 & 113 & 17 & 18 & 195 & 1019 & 300 & 1532 \\
\hline 6 & Coimbatore & 9 & 12 & 18 & 56 & 78 & 233 & 242 & 147 & 92 & 176 & 130 & 45 & 21 & 152 & 714 & 351 & 1238 \\
\hline 7 & Cuddalore & 50 & 39 & 30 & 32 & 30 & 60 & 90 & 100 & 90 & 200 & 380 & 249 & 89 & 92 & 340 & 829 & 1350 \\
\hline 8 & Dharmapuri & 10 & 12 & 18 & 56 & 78 & 63 & 72 & 77 & 68 & 176 & 130 & 45 & 22 & 152 & 280 & 351 & 805 \\
\hline 9 & Dindigul & 23 & 11 & 16 & 61 & 77 & 32 & 31 & 67 & 91 & 191 & 164 & 65 & 34 & 154 & 221 & 420 & 829 \\
\hline 10 & Erode & 15 & 11 & 17 & 54 & 93 & 30 & 33 & 64 & 86 & 168 & 114 & 34 & 26 & 162 & 213 & 316 & 717 \\
\hline 11 & Gudalur & 3 & 5 & 30 & 92 & 91 & 94 & 176 & 175 & 135 & 125 & 87 & 10 & 8 & 215 & 580 & 222 & 1025 \\
\hline 12 & Gundulper & 2 & 4 & 41 & 81 & 75 & 82 & 100 & 109 & 110 & 124 & 85 & 8 & 7 & 197 & 401 & 217 & 717 \\
\hline
\end{tabular}

\section{Volume 5 Issue 5, May 2016} www.ijsr.net 


\section{International Journal of Science and Research (IJSR) \\ ISSN (Online): 2319-7064}

Index Copernicus Value (2013): 6.14 | Impact Factor (2015): 6.391

\begin{tabular}{|c|c|c|c|c|c|c|c|c|c|c|c|c|c|c|c|c|c|c|}
\hline 13 & Hassan & 2 & 5 & 20 & 77 & 99 & 499 & 478 & 476 & 440 & 326 & 188 & 10 & 7 & 296 & 1893 & 524 & 2720 \\
\hline 14 & Geggada & 2 & 8 & 58 & 92 & 76 & 410 & 702 & 272 & 212 & 170 & 120 & 18 & 10 & 226 & 1596 & 308 & 2140 \\
\hline 15 & Devankote & 8 & 6 & 16 & 48 & 82 & 345 & 365 & 260 & 276 & 156 & 115 & 30 & 14 & 146 & 1246 & 301 & 1707 \\
\hline 16 & Hosur & 55 & 40 & 32 & 45 & 30 & 43 & 51 & 62 & 68 & 135 & 190 & 100 & 95 & 107 & 224 & 425 & 1851 \\
\hline 17 & Karur & 20 & 8 & 17 & 45 & 75 & 32 & 33 & 63 & 80 & 202 & 210 & 83 & 28 & 137 & 208 & 495 & 868 \\
\hline 18 & Kodaikanal & 15 & 15 & 50 & 95 & 85 & 352 & 450 & 250 & 125 & 120 & 120 & 70 & 30 & 230 & 1177 & 310 & 1647 \\
\hline 19 & Madikeri & 30 & 21 & 30 & 72 & 69 & 281 & 287 & 381 & 293 & 199 & 156 & 55 & 51 & 171 & 1242 & 410 & 1874 \\
\hline 20 & Madurai & 2 & 6 & 34 & 75 & 67 & 50 & 50 & 58 & 97 & 121 & 86 & 8 & 8 & 176 & 255 & 215 & 654 \\
\hline 21 & Mandya & 10 & 10 & 15 & 52 & 67 & 182 & 190 & 188 & 198 & 266 & 320 & 243 & 20 & 134 & 158 & 829 & 1741 \\
\hline 22 & Mereca & 4 & 9 & 59 & 93 & 77 & 512 & 700 & 483 & 473 & 176 & 123 & 20 & 13 & 229 & 2168 & 319 & 2729 \\
\hline 23 & Mettur & 8 & 11 & 20 & 46 & 68 & 74 & 71 & 79 & 62 & 170 & 125 & 44 & 19 & 134 & 286 & 339 & 778 \\
\hline 24 & Mettupalayam & 4 & 9 & 59 & 93 & 78 & 412 & 705 & 272 & 210 & 172 & 122 & 20 & 13 & 230 & 1599 & 314 & 2156 \\
\hline 25 & Mulhole & 2 & 5 & 42 & 96 & 77 & 260 & 301 & 311 & 315 & 228 & 188 & 50 & 7 & 215 & 1187 & 466 & 1875 \\
\hline 26 & Mysore & 60 & 48 & 30 & 50 & 26 & 148 & 160 & 160 & 169 & 230 & 400 & 305 & 108 & 106 & 637 & 935 & 1768 \\
\hline 27 & Nagapatnam & 10 & 10 & 16 & 48 & 81 & 33 & 33 & 63 & 85 & 265 & 215 & 141 & 20 & 145 & 214 & 625 & 1000 \\
\hline 28 & Namakkal & 35 & 5 & 14 & 60 & 73 & 27 & 25 & 37 & 60 & 163 & 160 & 70 & 40 & 147 & 149 & 393 & 729 \\
\hline 29 & Palani & 2 & 4 & 19 & 75 & 98 & 103 & 176 & 175 & 140 & 125 & 87 & 10 & 6 & 192 & 594 & 222 & 1004 \\
\hline 30 & Perambalur & 39 & 11 & 18 & 41 & 70 & 33 & 38 & 82 & 110 & 159 & 150 & 110 & 50 & 129 & 263 & 419 & 861 \\
\hline 31 & Puddukottai & 16 & 9 & 12 & 45 & 95 & 49 & 68 & 90 & 120 & 162 & 160 & 36 & 25 & 152 & 327 & 358 & 862 \\
\hline 32 & Salem & 16 & 19 & 20 & 39 & 65 & 34 & 47 & 75 & 90 & 105 & 180 & 132 & 35 & 124 & 246 & 417 & 822 \\
\hline 33 & Thanjavur & 17 & 18 & 25 & 62 & 66 & 35 & 39 & 65 & 95 & 185 & 130 & 60 & 35 & 153 & 234 & 375 & 797 \\
\hline 34 & Tiruchi & 28 & 12 & 14 & 43 & 77 & 30 & 37 & 92 & 114 & 183 & 180 & 76 & 40 & 134 & 273 & 439 & 886 \\
\hline 35 & Tumkur & 2 & 4 & 16 & 55 & 94 & 162 & 183 & 201 & 110 & 101 & 84 & 5 & 6 & 165 & 656 & 190 & 1017 \\
\hline 36 & Udagamandalam & 45 & 25 & 31 & 94 & 251 & 382 & 529 & 370 & 290 & 300 & 188 & 75 & 70 & 376 & 1541 & 563 & 2580 \\
\hline 37 & Vedapanyam & 70 & 59 & 40 & 55 & 40 & 50 & 60 & 70 & 80 & 140 & 350 & 236 & 169 & 135 & 260 & 726 & 1290 \\
\hline
\end{tabular}

Table 2: average monthly, seasonal and annual potencial evapotranspiration values of the stations of the cauvery basin in $\mathrm{mm}$

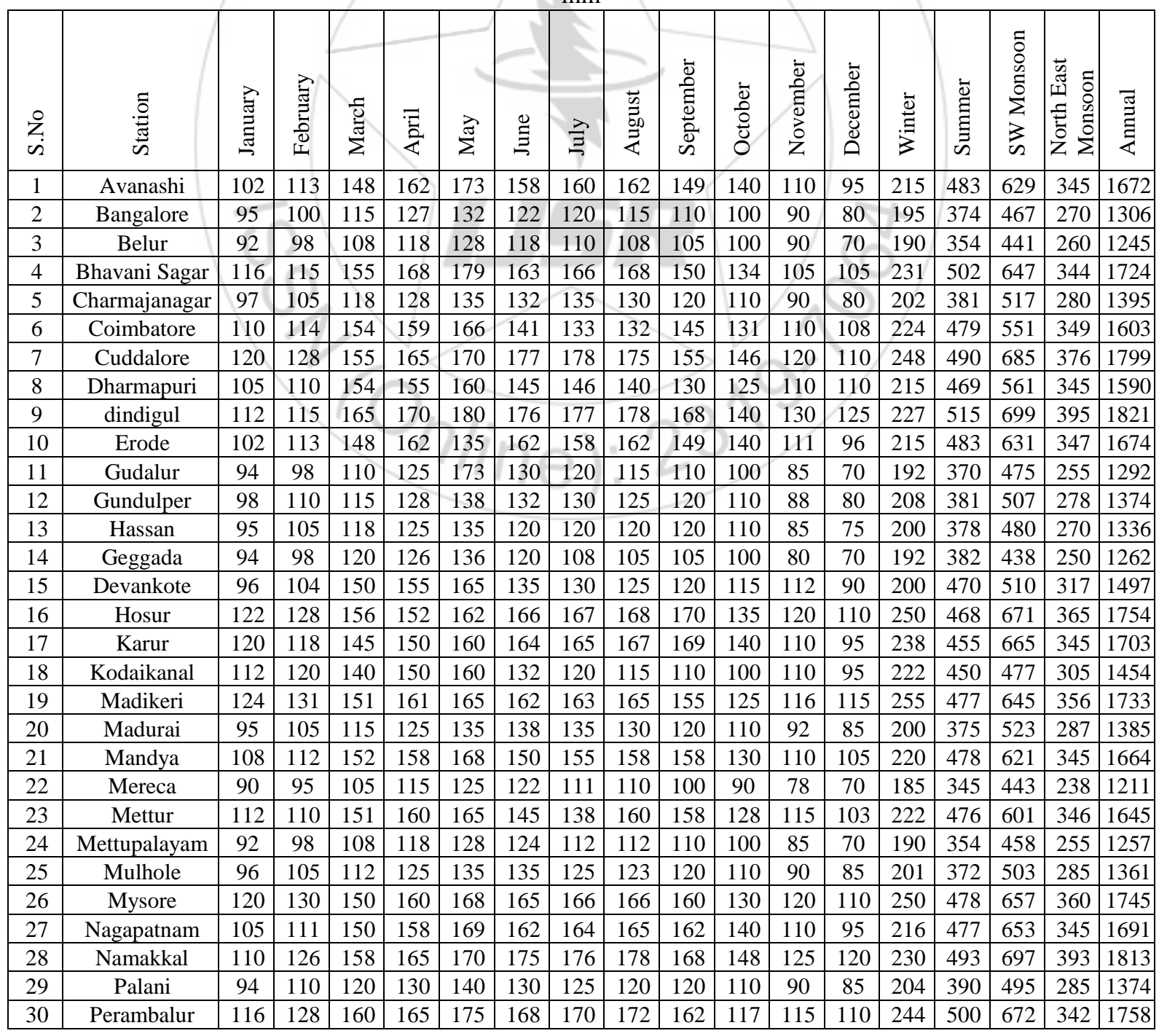




\section{International Journal of Science and Research (IJSR) \\ ISSN (Online): 2319-7064}

Index Copernicus Value (2013): 6.14 | Impact Factor (2015): 6.391

\begin{tabular}{|c|c|c|c|c|c|c|c|c|c|c|c|c|c|c|c|c|c|c|}
\hline 31 & Puddukottai & 110 & 115 & 154 & 160 & 170 & 155 & 158 & 160 & 155 & 135 & 122 & 110 & 225 & 484 & 628 & 367 & 1704 \\
\hline 32 & Salem & 126 & 126 & 152 & 162 & 172 & 165 & 167 & 168 & 158 & 130 & 115 & 115 & 252 & 486 & 658 & 360 & 1756 \\
\hline 33 & Thanjavur & 120 & 132 & 155 & 165 & 172 & 168 & 170 & 172 & 162 & 120 & 110 & 110 & 252 & 492 & 672 & 340 & 1752 \\
\hline 34 & Tiruchi & 120 & 125 & 152 & 162 & 173 & 164 & 165 & 167 & 157 & 133 & 115 & 120 & 245 & 487 & 653 & 368 & 1753 \\
\hline 35 & Tumkur & 98 & 102 & 118 & 128 & 138 & 134 & 132 & 130 & 125 & 110 & 90 & 85 & 200 & 384 & 521 & 285 & 1390 \\
\hline 36 & Udagamandalam & 90 & 95 & 125 & 120 & 130 & 102 & 92 & 90 & 85 & 75 & 75 & 70 & 185 & 355 & 369 & 220 & 1109 \\
\hline 37 & Vedapanyam & 125 & 129 & 146 & 156 & 172 & 175 & 176 & 178 & 165 & 135 & 120 & 110 & 254 & 474 & 694 & 365 & 1787 \\
\hline
\end{tabular}

Table 3: average monthly, seasonal and annual actual evapotranspiration values of the stations of the cauvery basin in $\mathrm{mm}$

\begin{tabular}{|c|c|c|c|c|c|c|c|c|c|c|c|c|c|c|c|c|c|c|}
\hline $\begin{array}{l}\stackrel{0}{z} \\
\dot{n}\end{array}$ & . & $\underset{己}{\stackrel{己}{\Xi}}$ & 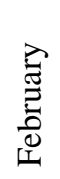 & 总 & 诺 & $\stackrel{\vec{\Sigma}}{\Sigma}$ & $\stackrel{\Xi}{\Xi}$ & $\stackrel{\lambda}{\Xi}$ & 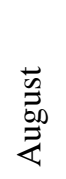 & 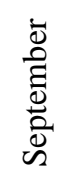 & $\begin{array}{l}\overline{0} \\
\stackrel{0}{0} \\
\stackrel{0}{0}\end{array}$ & $\begin{array}{l}\dot{\bar{D}} \\
\text { है } \\
\bar{D} \\
\text { ठ }\end{array}$ & 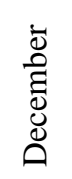 & 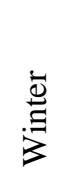 & $\underset{\Xi}{\bar{\Xi}}$ & $\begin{array}{ll}\vec{w} & \\
\infty & 0 \\
3 & 0 \\
\equiv & 0 \\
0 & 0 \\
0 & 0 \\
\omega & \Sigma\end{array}$ & 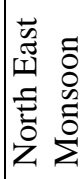 & 㞼 \\
\hline 1 & Avanashi & 72 & 59 & 60 & 74 & 103 & 42 & 37 & 60 & 98 & 140 & 110 & 90 & 131 & 267 & 237 & 340 & 975 \\
\hline 2 & Bangalore & 80 & 85 & 75 & 70 & 104 & 66 & 102 & 115 & 110 & 100 & 90 & 40 & 165 & 249 & 393 & 230 & 977 \\
\hline 3 & Belur & 90 & 90 & 80 & 75 & 92 & 118 & 110 & 108 & 105 & 100 & 90 & 70 & 180 & 247 & 441 & 260 & 1245 \\
\hline 4 & Bhavani Sagar & 81 & 65 & 60 & 71 & 104 & 20 & 29 & 38 & 75 & 134 & 105 & 105 & 146 & 235 & 162 & 344 & 887 \\
\hline 5 & ajanagar & 83 & 80 & 85 & 88 & 87 & 132 & 135 & 130 & 120 & 110 & 90 & 58 & 163 & 260 & 347 & 258 & 1028 \\
\hline 6 & Coin & 85 & 58 & 63 & 62 & 80 & 141 & 133 & 132 & 120 & 131 & 110 & 100 & 143 & 205 & 184 & 341 & 873 \\
\hline 7 & & 110 & 78 & 50 & 52 & 32 & 60 & 91 & 110 & 91 & 146 & 120 & 110 & 188 & 134 & 352 & 376 & 1052 \\
\hline 8 & Dhar & 89 & 70 & 58 & 56 & 80 & 35 & 43 & 48 & 58 & 125 & 110 & 110 & 159 & 212 & 184 & 345 & 900 \\
\hline 9 & uit & 82 & 61 & 60 & 61 & 78 & 34 & 32 & 68 & 92 & 140 & 130 & 110 & 143 & 199 & 226 & 380 & 948 \\
\hline 10 & & 81 & 56 & 50 & 71 & 95 & 40 & 39 & 66 & 87 & 140 & 111 & 77 & 137 & 219 & 232 & 328 & 916 \\
\hline 11 & S & 92 & 90 & 80 & 98 & 98 & 130 & 120 & 115 & 110 & 100 & 85 & 60 & 182 & 273 & 475 & 245 & 1175 \\
\hline 12 & Gun & 88 & 85 & 80 & 85 & 77 & 84 & 101 & 119 & 120 & 110 & 88 & 55 & 173 & 242 & 424 & 253 & 1064 \\
\hline 13 & & 92 & 90 & 82 & 78 & 135 & 120 & 120 & 120 & 120 & 110 & 85 & 75 & 182 & 244 & 482 & 255 & 1169 \\
\hline 14 & & 92 & 92 & 80 & 94 & 78 & 120 & 108 & 105 & 105 & 100 & 80 & 70 & 184 & 252 & 438 & 250 & 1262 \\
\hline 15 & $\bar{D}$ & 86 & 80 & 60 & 55 & 83 & 135 & 130 & 125 & 120 & 115 & 112 & 90 & 166 & 195 & 251 & 307 & 919 \\
\hline 16 & & 112 & 98 & 66 & 52 & 32 & 44 & 52 & 63 & 70 & 135 & 120 & 110 & 210 & 150 & 29 & 365 & 54 \\
\hline 17 & & 80 & 73 & 55 & 55 & 76 & 33 & 34 & 64 & 82 & 140 & 110 & 95 & 153 & 186 & 213 & 332 & 884 \\
\hline 18 & $\mathrm{Kod}$ & 87 & 70 & 90 & 90 & 88 & 132 & 120 & 115 & 110 & 100 & 110 & 95 & 157 & 276 & 477 & 305 & 1454 \\
\hline 19 & & 97 & 78 & 73 & 73 & 75 & 162 & 163 & 165 & 155 & 125 & 116 & 115 & 175 & 221 & 247 & 356 & 999 \\
\hline 20 & & 92 & 85 & 75 & 78 & 69 & 51 & 51 & 59 & 100 & 110 & 92 & 58 & 177 & 222 & 261 & 260 & 920 \\
\hline 21 & $\mathrm{~N}$ & 90 & 72 & 52 & 54 & 68 & 150 & 155 & 158 & 158 & 130 & 110 & 105 & 162 & 174 & 183 & 333 & 890 \\
\hline 22 & & 90 & 92 & 85 & 95 & 80 & 122 & 111 & 110 & 100 & 90 & 78 & 70 & 182 & 260 & 443 & 238 & 1211 \\
\hline 23 & $M$ & 87 & 88 & 73 & 48 & 70 & 35 & 42 & 50 & 54 & 128 & 115 & 94 & 175 & 191 & 181 & 337 & 884 \\
\hline 24 & Mettl & 90 & 95 & 85 & 95 & 80 & 124 & 112 & 112 & 110 & 100 & 85 & 65 & 185 & 260 & 458 & 250 & 1257 \\
\hline 25 & & 90 & 90 & 75 & 98 & 80 & 135 & 125 & 123 & 120 & 110 & 90 & 85 & 180 & 253 & 406 & 255 & 1094 \\
\hline 26 & Myso & 110 & 98 & 85 & 60 & 28 & 150 & 162 & 161 & 160 & 130 & 120 & 110 & 208 & 173 & 223 & 360 & 1147 \\
\hline 27 & & 85 & 65 & 60 & 50 & 83 & 34 & 34 & 64 & 87 & 140 & 110 & 95 & 150 & 193 & 219 & 335 & 762 \\
\hline 28 & kkal & 82 & 60 & 50 & 62 & 75 & 28 & 26 & 38 & 62 & 148 & 125 & 120 & 142 & 187 & 154 & 393 & 876 \\
\hline 29 & Palani & 92 & 80 & 80 & 76 & 100 & 130 & 125 & 120 & 120 & 110 & 90 & 60 & 172 & 256 & 495 & 260 & 1183 \\
\hline 30 & $\mathrm{Per}$ & 97 & 66 & 55 & 50 & 72 & 34 & 39 & 85 & 112 & 117 & 115 & 110 & 163 & 177 & 270 & 342 & 952 \\
\hline 31 & Puddukott: & 86 & 69 & 62 & 50 & 98 & 50 & 69 & 95 & 125 & 135 & 122 & 95 & 155 & 210 & 339 & 352 & 1056 \\
\hline 32 & Salem & 82 & 53 & 25 & 40 & 66 & 35 & 40 & 76 & 102 & 130 & 115 & 115 & 135 & 131 & 253 & 360 & 879 \\
\hline 33 & anjavur & 90 & 80 & 75 & 65 & 68 & 36 & 40 & 68 & 98 & 120 & 110 & 110 & 170 & 208 & 242 & 340 & 960 \\
\hline 34 & TheniTiruchi & 82 & 66 & 62 & 50 & 78 & 31 & 38 & 97 & 116 & 133 & 115 & 120 & 148 & 190 & 282 & 368 & 998 \\
\hline 35 & Tumkur & 83 & 80 & 78 & 58 & 96 & 134 & 132 & 130 & 125 & 110 & 90 & 75 & 163 & 232 & 402 & 245 & 1042 \\
\hline 36 & Udagamandalam & 88 & 85 & 85 & 98 & 130 & 102 & 92 & 90 & 85 & 75 & 75 & 70 & 173 & 313 & 369 & 220 & 1109 \\
\hline 37 & Vedapanyam & 120 & 80 & 75 & 65 & 42 & 51 & 61 & 71 & 82 & 135 & 120 & 110 & 200 & 178 & 265 & 365 & 1239 \\
\hline
\end{tabular}

Table.4 : average monthly, seasonal and annual water deficit values of the stations of the cauvery basin in $\mathrm{mm}$

\begin{tabular}{|c|c|c|c|c|c|c|c|c|c|c|c|c|c|c|c|c|c|c|}
\hline $\begin{array}{l}\dot{z} \\
\dot{\infty}\end{array}$ & 䒿 & 莺 & 胥 & 胥 & $\frac{\bar{z}}{4}$ & $\overrightarrow{\mathrm{E}}$ & $\stackrel{\mathscr{\Xi}}{\Xi}$ & 豆 & 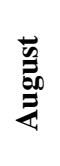 & 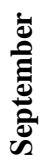 & 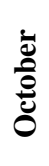 & 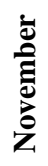 & 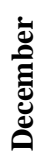 & $\stackrel{\vec{\Xi}}{\Xi}$ & $\stackrel{\grave{\Xi}}{\stackrel{\Xi}{\Xi}}$ & 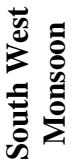 & 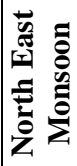 & 臭 \\
\hline 1 & & 30 & 54 & 88 & 88 & 60 & 116 & 123 & 102 & 51 & 0 & 0 & 5 & 84 & 236 & 392 & 5 & 717 \\
\hline 2 & Bangalore & 15 & 15 & 40 & 57 & 28 & 56 & 18 & 0 & 0 & 0 & 0 & 40 & 30 & 125 & 74 & 40 & 269 \\
\hline 3 & Belur & 2 & 8 & 20 & 43 & 36 & 0 & 0 & 0 & 0 & 0 & 0 & 2 & 10 & 99 & 0 & 2 & 111 \\
\hline 4 & havani Sagar & 35 & 40 & 95 & 97 & 75 & 143 & 137 & 130 & 75 & 0 & 0 & 0 & 75 & 267 & 485 & 0 & 827 \\
\hline 5 & Charmajanagar & 14 & 25 & 33 & 40 & 48 & 0 & 0 & 0 & 0 & 0 & 0 & 22 & 39 & 121 & 0 & 22 & 182 \\
\hline
\end{tabular}


International Journal of Science and Research (IJSR)

ISSN (Online): 2319-7064

Index Copernicus Value (2013): 6.14 | Impact Factor (2015): 6.391

\begin{tabular}{|c|c|c|c|c|c|c|c|c|c|c|c|c|c|c|c|c|c|c|}
\hline 6 & Coimbatore & 25 & 56 & 91 & 97 & 86 & 0 & 0 & 0 & 87 & 0 & 0 & 0 & 81 & 274 & 87 & 8 & 450 \\
\hline 7 & Cuddalore & 10 & 50 & 105 & 113 & 138 & 115 & 87 & 65 & 64 & 0 & 0 & 0 & 60 & 356 & 331 & 0 & 747 \\
\hline 8 & Dharmapuri & 16 & 40 & 76 & 99 & 80 & 110 & 103 & 92 & 72 & 0 & 0 & 0 & 56 & 255 & 377 & 0 & 688 \\
\hline 9 & Dindigul & 30 & 54 & 105 & 109 & 102 & 142 & 145 & 110 & 76 & 0 & 0 & 4 & 84 & 316 & 473 & 15 & 888 \\
\hline 10 & Erode & 21 & 57 & 98 & 91 & 40 & 122 & 119 & 94 & 62 & 0 & 0 & 19 & 78 & 229 & 397 & 19 & 723 \\
\hline 11 & Gudalur & 0 & 8 & 30 & 27 & 75 & 0 & 0 & 0 & 0 & 0 & 0 & 10 & 08 & 132 & 0 & 10 & 150 \\
\hline 12 & Gundulper & 10 & 25 & 35 & 43 & 61 & 48 & 29 & 6 & 0 & 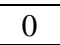 & 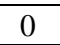 & 25 & 35 & 139 & 83 & 25 & 282 \\
\hline 13 & Hassan & 3 & 15 & 36 & 47 & 33 & 0 & 0 & 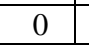 & 0 & 0 & 0 & 0 & 18 & 116 & 0 & 0 & 134 \\
\hline 14 & Geggada & 2 & 6 & 40 & 32 & 58 & 0 & 0 & 0 & 0 & 0 & 0 & 0 & 8 & 130 & 0 & 0 & 138 \\
\hline 15 & Devankote & 10 & 24 & 90 & 100 & 82 & 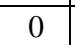 & 0 & 0 & 0 & 0 & 0 & & 34 & 272 & 0 & 0 & 306 \\
\hline 16 & osur & 10 & 30 & 90 & 100 & 130 & 122 & 115 & 105 & 100 & 0 & 0 & ( & 40 & 320 & 442 & 0 & 802 \\
\hline 17 & 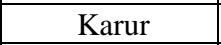 & 40 & 45 & 90 & 95 & 84 & 131 & 131 & 103 & 87 & 0 & 0 & 0 & 85 & 269 & 452 & 0 & 806 \\
\hline 18 & Kodaikanal & 25 & 40 & 50 & 70 & 72 & 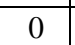 & 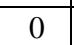 & 0 & 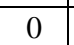 & 0 & 0 & & 65 & 192 & 0 & 0 & 257 \\
\hline 19 & Madikeri & 27 & 53 & 78 & 88 & 90 & 0 & 0 & 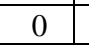 & 0 & 0 & 0 & 0 & 80 & 256 & 0 & 0 & 336 \\
\hline 20 & $\mathrm{M}$ & 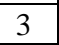 & 20 & 60 & 47 & 66 & 87 & 84 & 71 & 20 & 0 & 0 & 27 & 23 & 173 & 262 & 27 & 485 \\
\hline 21 & Mere & 0 & 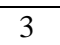 & 20 & 20 & 45 & - & 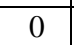 & 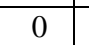 & 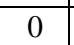 & 0 & 0 & & & 85 & 0 & 0 & 88 \\
\hline 22 & Mandya & 18 & 40 & 100 & 104 & 100 & 0 & 0 & 0 & 0 & 0 & 0 & 0 & 58 & 304 & 0 & 0 & 774 \\
\hline 23 & Mettur & 25 & 22 & 78 & 112 & 95 & 110 & 96 & \begin{tabular}{|l|l|}
110 \\
\end{tabular} & 104 & 0 & 0 & 0 & 47 & 285 & 420 & 0 & 752 \\
\hline 24 & Mettupalayar & 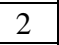 & 3 & 23 & 43 & 48 & 0 & 0 & 0 & 0 & 0 & 0 & & 5 & 114 & 0 & 5 & 124 \\
\hline 25 & Mulhole & 6 & 15 & 37 & 78 & 55 & 0 & 0 & 0 & 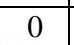 & 0 & 0 & 0 & 21 & 170 & 0 & 0 & 191 \\
\hline 26 & Mysore & 10 & 32 & 65 & 27 & 140 & 10 & 0 & 0 & 0 & 0 & 0 & 0 & 42 & 232 & 10 & 0 & 284 \\
\hline 27 & Nagapatna & 20 & 46 & 90 & 108 & 86 & 128 & 130 & 101 & 75 & 0 & O & & 66 & 284 & 434 & 0 & 784 \\
\hline 28 & Namakkal & 28 & 60 & 108 & 103 & 95 & 147 & 150 & 140 & 106 & 0 & 0 & & 88 & 306 & 543 & 0 & 937 \\
\hline 29 & Palani & 2 & 30 & 40 & 54 & 40 & 0 & 0 & 0 & 0 & 0 & 0 & 25 & 32 & 134 & 0 & 25 & 191 \\
\hline 30 & Perambal & 19 & 62 & 105 & 115 & 103 & 134 & 131 & 87 & 50 & 0 & 0 & 0 & 81 & 323 & 402 & 0 & 806 \\
\hline 31 & Puddukot & 24 & 46 & 92 & 100 & 72 & 105 & 89 & 65 & 30 & 0 & 0 & 15 & 70 & 264 & \begin{tabular}{|l|}
289 \\
\end{tabular} & 15 & 638 \\
\hline 32 & Salem & 44 & 73 & 127 & 122 & 106 & 130 & 127 & 92 & 56 & 0 & 0 & 0 & 117 & 355 & \begin{tabular}{|l|}
405 \\
\end{tabular} & 0 & 877 \\
\hline 33 & Thanjavur & 30 & 52 & 80 & 100 & 104 & 132 & 130 & 104 & 64 & 0 & 0 & 0 & 82 & 284 & 430 & 0 & 796 \\
\hline 34 & & 38 & 59 & 190 & 12 & 95 & 133 & 127 & 70 & 41 & 0 & 0 & & 97 & 297 & 371 & 0 & 765 \\
\hline 35 & Tumkur & 15 & 22 & 40 & 70 & 42 & 0 & 0 & 0 & 0 & 0 & 0 & 10 & 37 & 152 & 0 & 10 & 199 \\
\hline 36 & Udagamandalam & 2 & 10 & 40 & 22 & 0 & 0 & 0 & 0 & 0 & 0 & 0 & 0 & 12 & 62 & 0 & 0 & 74 \\
\hline 37 & Vedapanyam & 5 & 49 & 71 & 91 & 130 & 124 & 115 & 107 & 83 & 0 & 0 & 0 & 54 & 292 & 429 & 0 & 775 \\
\hline
\end{tabular}

Table 5: average monthly, seasonal and annual water surplus values of the stations of the cauvery basin in $\mathrm{mm}$

\begin{tabular}{|c|c|c|c|c|c|c|c|c|c|c|c|c|c|c|c|c|c|c|}
\hline$\sum_{\dot{z}}^{0}$ & 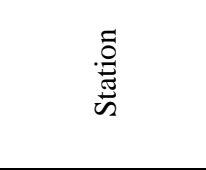 & 志 & 矛 & $\begin{array}{l}\overline{0} \\
\frac{\bar{J}}{2}\end{array}$ & $\overline{\bar{c}}$ & $\sum^{\mathrm{I}}$ & $\Xi$ & 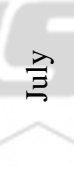 & $\left|\begin{array}{l}\vec{v} \\
\overrightarrow{5} \\
\vec{z} \\
\vec{z}\end{array}\right|$ & 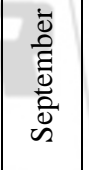 & $\begin{array}{l}\overline{0} \\
\overline{0} \\
\overline{0}\end{array}$ & $\begin{array}{l}\dot{\bar{D}} \\
\bar{z} \\
\overline{0} \\
\dot{0} \\
z\end{array}$ & 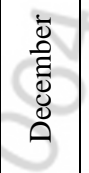 & 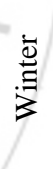 & 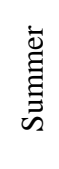 & 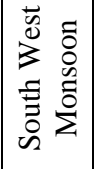 & 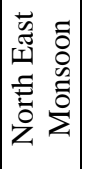 & 氶 \\
\hline 1 & Avanashi & 0 & 0 & 0 & 0 & 0 & 0 & 0 & 0 & 0 & +39 & 0 & 0 & 0 & 0 & 0 & \begin{tabular}{|l|}
+39 \\
\end{tabular} & +39 \\
\hline 2 & Bangalore & 0 & 0 & 0 & 0 & 0 & 0 & 0 & 0 & +18 & 0 & 0 & 0 & 0 & 0 & 0 & \begin{tabular}{|l|}
+18 \\
\end{tabular} & +18 \\
\hline 3 & Belur & 0 & 0 & 0 & 0 & 0 & +274 & +548 & +185 & +185 & +66 & +30 & 0 & 0 & 0 & +1192 & \begin{tabular}{|l|}
+30 \\
\end{tabular} & +1222 \\
\hline 4 & Bhavani Sagar & 0 & 0 & 0 & 0 & 0 & 0 & 0 & 0 & 0 & +43 & 0 & 0 & 0 & 0 & 0 & \begin{tabular}{|l|}
+43 \\
\end{tabular} & +43 \\
\hline 5 & Charmajanagar & 0 & 0 & 0 & 0 & 0 & +114 & +230 & +73 & +85 & +60 & +23 & 0 & 0 & 0 & +502 & \begin{tabular}{|l|}
+83 \\
\end{tabular} & \begin{tabular}{rl|}
+585 \\
\end{tabular} \\
\hline 6 & Coimbatore & 0 & 0 & 0 & 0 & 0 & \begin{tabular}{|l|}
+92 \\
\end{tabular} & +109 & +15 & 0 & +45 & +20 & 0 & 0 & 0 & +216 & \begin{tabular}{|l|}
+65 \\
\end{tabular} & \begin{tabular}{l|}
+281 \\
\end{tabular} \\
\hline 7 & Cuddalore & 0 & 0 & 0 & 0 & 0 & 0 & 0 & 0 & 0 & +54 & +260 & +139 & 0 & 0 & 0 & +453 & +453 \\
\hline 8 & Dharmapuri & 0 & 0 & 0 & 0 & 0 & 0 & 0 & 0 & 0 & +51 & +20 & 0 & 0 & 0 & 0 & +71 & +71 \\
\hline 9 & Dindigul & 0 & 0 & 0 & 0 & 0 & 0 & 0 & 0 & 0 & +51 & \begin{tabular}{|l|}
+34 \\
\end{tabular} & 0 & 0 & 0 & 0 & \begin{tabular}{|l|}
+85 \\
\end{tabular} & +85 \\
\hline 10 & Erode & 0 & 0 & 0 & 0 & 0 & 0 & 0 & 0 & 0 & +28 & \begin{tabular}{|l|}
+03 \\
\end{tabular} & 0 & 0 & 0 & 0 & $\begin{array}{l}+31 \\
\end{array}$ & +31 \\
\hline 11 & Gudalur & 0 & 0 & 0 & 0 & 0 & 0 & +56 & +60 & +25 & +25 & 0 & 0 & 0 & 0 & +141 & +25 & +166 \\
\hline 12 & Gundulper & 0 & 0 & 0 & 0 & 0 & 0 & 0 & 0 & 0 & +14 & 0 & 0 & 0 & 0 & 0 & \begin{tabular}{|l|}
+14 \\
\end{tabular} & \begin{tabular}{ll|}
+14 \\
\end{tabular} \\
\hline 13 & Hassan & 0 & 0 & 0 & 0 & 0 & +379 & +358 & +356 & +320 & +216 & +103 & 0 & 0 & 0 & +1413 & \begin{tabular}{|l|}
+319 \\
\end{tabular} & $\begin{array}{l}+1732 \\
+17\end{array}$ \\
\hline 14 & Geggada & 0 & 0 & 0 & 0 & 0 & +290 & +594 & +167 & +107 & +70 & +40 & 0 & 0 & 0 & +1158 & +110 & +1268 \\
\hline 15 & Devankote & 0 & 0 & 0 & 0 & 0 & +210 & +235 & +135 & +156 & +41 & \begin{tabular}{l|}
+03 \\
\end{tabular} & 0 & 0 & 0 & $\begin{array}{l}+736 \\
\end{array}$ & \begin{tabular}{|l|}
+44 \\
\end{tabular} & +780 \\
\hline 16 & Hosur & 0 & 0 & 0 & 0 & 0 & 0 & 0 & 0 & 0 & 0 & +70 & 0 & 0 & 0 & 0 & +70 & +70 \\
\hline 17 & Karur & 0 & 0 & 0 & 0 & 0 & 0 & 0 & 0 & 0 & +62 & +100 & 0 & 0 & 0 & 0 & $\begin{array}{r}+162 \\
\end{array}$ & +162 \\
\hline 18 & Kodaikanal & 0 & 0 & 0 & 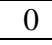 & 0 & +220 & +330 & +115 & 0 & 0 & 0 & 0 & 0 & 0 & +665 & 0 & +665 \\
\hline 19 & Madikeri & 0 & 0 & 0 & 0 & 0 & +192 & +287 & +85 & 0 & 0 & 0 & 0 & 0 & 0 & +564 & 0 & \begin{tabular}{|l|l|}
+564 \\
\end{tabular} \\
\hline 20 & Madurai & 0 & 0 & 0 & 0 & 0 & 0 & 0 & 0 & 0 & +11 & 0 & 0 & 0 & 0 & 0 & +11 & +11 \\
\hline 21 & Mereca & 0 & 0 & 0 & 0 & 0 & +390 & +589 & +373 & +373 & +86 & +45 & 0 & 0 & 0 & +1734 & +131 & +1865 \\
\hline 22 & Mandya & 0 & 0 & 0 & 0 & 0 & +32 & +35 & +30 & \begin{tabular}{|l|}
+40 \\
\end{tabular} & +136 & +219 & +138 & 0 & 0 & \begin{tabular}{|l|}
+137 \\
\end{tabular} & +493 & \begin{tabular}{|l|}
+630 \\
\end{tabular} \\
\hline 23 & Mettur & 0 & 0 & 0 & 0 & 0 & 0 & 0 & 0 & 0 & +58 & +10 & 0 & 0 & 0 & 0 & +68 & +68 \\
\hline 24 & Mettupalayan & 0 & 0 & 0 & 0 & 0 & +188 & $\begin{array}{r}+593 \\
\end{array}$ & +160 & +100 & +72 & +37 & 0 & 0 & 0 & +1041 & \begin{tabular}{|l|}
+109 \\
\end{tabular} & +1150 \\
\hline 25 & Mulhole & 0 & 0 & 0 & 0 & 0 & +125 & +177 & +188 & \begin{tabular}{|l|}
+195 \\
\end{tabular} & +118 & \begin{tabular}{|l|}
+98 \\
\end{tabular} & 0 & 0 & 0 & \begin{tabular}{|l|}
+685 \\
\end{tabular} & \begin{tabular}{|l|}
+216 \\
\end{tabular} & $\begin{array}{l}+901 \\
\end{array}$ \\
\hline
\end{tabular}


International Journal of Science and Research (IJSR)

ISSN (Online): 2319-7064

Index Copernicus Value (2013): 6.14 | Impact Factor (2015): 6.391

\begin{tabular}{|c|c|c|c|c|c|c|c|c|c|c|c|c|c|c|c|c|c|c|}
\hline 26 & Mysore & 0 & 0 & 0 & 0 & 0 & 0 & 0 & 0 & +69 & +100 & +280 & +195 & 0 & 0 & +69 & +595 & +644 \\
\hline 27 & Nagapatnam & 0 & 0 & 0 & 0 & 0 & 0 & 0 & 0 & 0 & +125 & +105 & +46 & 0 & 0 & 0 & +276 & +276 \\
\hline 28 & Namakkal & 0 & 0 & 0 & 0 & 0 & 0 & 0 & 0 & 0 & +25 & +45 & 0 & 0 & 0 & 0 & +70 & +70 \\
\hline 29 & Palani & 0 & 0 & 0 & 0 & 0 & 0 & +51 & +50 & +20 & +15 & 0 & 0 & 0 & 0 & +121 & +15 & +136 \\
\hline 30 & Perambalur & 0 & 0 & 0 & 0 & 0 & 0 & 0 & 0 & 0 & +42 & +35 & 0 & 0 & 0 & 0 & +77 & +77 \\
\hline 31 & Puddukottai & 0 & 0 & 0 & 0 & 0 & 0 & 0 & 0 & 0 & +27 & +38 & 0 & 0 & 0 & 0 & +65 & +65 \\
\hline 32 & Salem & 0 & 0 & 0 & 0 & 0 & 0 & 0 & 0 & 0 & 0 & +65 & +17 & 0 & 0 & 0 & +82 & +82 \\
\hline 33 & Thanjavur & 0 & 0 & 0 & 0 & 0 & 0 & 0 & 0 & 0 & +65 & +20 & 0 & 0 & 0 & 0 & +85 & +85 \\
\hline 34 & Tiruchi & 0 & 0 & 0 & 0 & 0 & 0 & 0 & 0 & 0 & +50 & +65 & 0 & 0 & 0 & 0 & +115 & +115 \\
\hline 35 & Tumkur & 0 & 0 & 0 & 0 & 0 & +28 & +451 & +71 & 0 & 0 & 0 & 0 & 0 & 0 & +550 & 0 & +550 \\
\hline 36 & Udagamandalam & 0 & 0 & 0 & 0 & +121 & +280 & +437 & +280 & +205 & +225 & +113 & 0 & 0 & 0 & +1202 & +338 & +1661 \\
\hline 37 & Vedapanyam & 0 & 0 & 0 & 0 & 0 & 0 & 0 & 0 & 0 & +05 & +230 & +26 & 0 & 0 & 0 & +261 & +261 \\
\hline
\end{tabular}

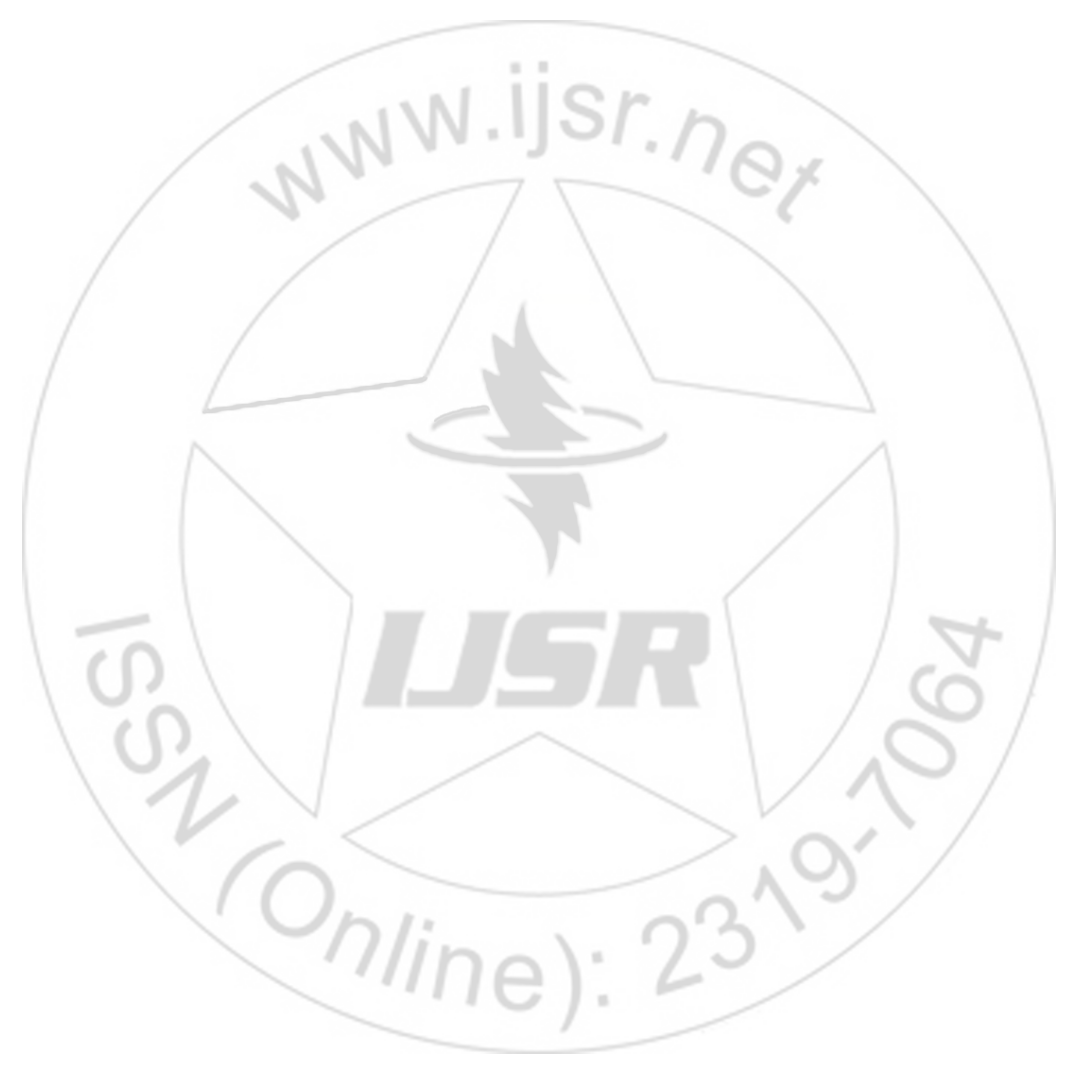

Volume 5 Issue 5, May 2016

www.ijsr.net 